\title{
SUBSPECIALTY PLATFORM SESSION
}

\author{
CARDIOLOGY II \\ Wednesday, April 29, 1987; 9:00 A.M. - 12:30 P.M. \\ MARINA BALLROOM 1 \\ (Hotel Convention Center)
}

Moderators: Welton Gersony and Roberta Williams

1. 9:00 THE ELECTROPHYSIOLOGIC EFFECTS OF SOTALOL IN THE IMMATURE MAMMALIAN HEART. Hui Xu, Jorge McCormack, Adrienne Stolfi, Henry Gelband, Arthur S. Pickoff (Spon. by Arthur S. Pickoff). Univ. of Miami School of Med., Dept. of Pediatrics, Miami, FL. (Abstract 143).

2. 9:15 THE EFFECTS OF HYPOXIA AND ADENOSINE ON THE ELECTRO-PHYSIOLOGIC FUNCTION OF THE ADULT AND NEONATAL RABBIT ATRIOVENTRICULAR NODE. Ming-Lon Young, Brian M. Ramza, Ronald W. Joyner (Spon. by Ronald M. Lauer). Univ. of Iowa, Depts. of Pediatrics and Phys., Iowa City, IA. (Abstract 145).

3. 9:30 CHARACTERIZATION OF SINUS NODE REFRACTORINESS AND SINOATRIAL CONDUCTION DURING ACUTE HYPOXIA. Steven M. Yabek. Univ. of New Mexico School of Med., Dept. of Pediatrics, Albuquerque, NM. (Abstract 144).

4. 9:45 MECHANISM OF 2:1 ATRIOVENTRICULAR BLOCK IN INFANTS WITH CONGENITAL LONG QT SYNDROME. William A. Scott, Burt I. Bromberg, Macdonald Dick, II. C.S. Mott Children's Hosp., Univ. of Michigan, Div. of Pediatric Cardiology, Ann Arbor, MI. (Abstract 130).

5. 10:00 "IDIOPATHIC" LEFT VENTRICULAR TACHYCARDIA IN CHILDREN: CHARACTERIZATION AND TREATMENT. Kazuyuki Koike, Peter S. Hesslein, Cameron D. Finlay, William G. Williams, Robert M. Freedom, Richard D. Rowe. The Hospital for Sick Children, Divisions of Cardiology and Cardiovascular Surgery, Toronto, Canada. (Abstract 110).

6. 10:15 EXERCISE STUDIES IN CHILDREN WITH TRANSPOSITION OF THE GREAT ARTERIES (TGA) AFTER MUSTARD REPAIR. J. Reisman, G. Canny, N. Musewe, D. Wilkes, H. Levison, L. Benson. Cardiol. \& Chest Div., Hospital for Sick Children, Toronto, Canada. (Abstract 124).

7. 10:30 EBSTEIN'S ANOMALY: PRE AND POSTOPERATIVE EXERCISE CARDIORESPIRATORY FUNCTION. David J. Driscol1, Carl Mottram, Gordon K. Danielson. Mayo Clinic and Mayo Foundation, Section of Pediatric Cardiology, Dept. of Pediatrics, Rochester, MN. (Abstract 101).

8. 10:45 THE UNNATURAL HISTORY OF AORTIC STENOSIS. William Berman, Jr., Steven M. Yabek, Raymond R. Fripp, Terrence Dillon, Rochelle Burstein. UNM School of Med., UNM Hosp., Pediatrics Dept., Albuquerque, NM. (Abstract 85).

9. 11:00 RECURRENCE OF CONGENITAL HEART DEFECTS IN PROGENY OF AFFECTED MEN VS. WOMEN. Ruth Whittemore, James A. Wells, Margaret R. Wright. Yale Univ. Sch. of Med. and Yale-New Haven Hosp., Dept. of Pediatrics, New Haven, CT. (Abstract 141). 
10. 11:15 CARDIAC SIZE AND FUNCTION IN SCHOOL ATHLETES AT REST AND AFTER EXERCISE. Tarek S. Husayni, Juan Longhi, Marc Puczynski, Regina Smarto, Anthony F. Cutilletta. Loyola Univ. Stritch School of Medicine, Dept. of Pediatrics, Maywood, IL. (Abstract 106).

11. 11:30 ESOPHAGEAL DYSMOTILITY: A CAUSE OF CHEST PAIN IN CHILDHOOD MITRAL VALVE PROLAPSE (MVP). Paul K. Woolf, Stuart Berezin, Marvin S. Medow, Leonard J. Newman, Julian M. Stewart, Michael H. Gewitz (Spon. by Lawrence Shapiro). New York Medical College, Westchester Medical Center, Dept. of Pediatrics, Valhalla, NY. (Abstract 142).

12. 11:45 DO LONG TERM RESULTS JUSTIFY PEDIATRIC HEART TRANSPLANTATION? David Baum, Edward Stinson, Philip Oyer, John Baldwin, Sharon Hunt, Vaughn Starnes, Norman Shumway. Depts. of Pediatrics and Cardiac Surgery, Stanford Univ. Medical Center, Stanford, CA. (Abstract 79).

13. 12:00 DOSE REQUIREMENTS FOR MAXIMAL EFFECTS OF PROPRANOLOL IN PEDIATRIC PATIENTS. Daphne T. Hsu, Daniel T. Williams, Henrietta Wolland, Welton M. Gersony. Columbia Univ. College of Physicians and Surgeons, Dept. of Pediatrics, New York City, NY. (Abstract 105).

14. 12:15 IS THE PLASMA DIGOXIN IMMUNOREACTIVITY OF PREGNANCY ASSOCIATED WITH DIGITALIS-LIKE ( $\mathrm{Na}+\mathrm{K})$ ATPase INHIBITION? Richard Ringel, John Hamlyn, Gerard Pinkas (Spon. by Allen Schwartz). Univ. of Maryland, Depts. of Pediatrics and Physiology, Baltimore, MD. (Abstract 125).

\section{SUBSPECIALTY PLATFORM SESSION}

DEVELOPMENTAL BIOLOGY I

Wednesday, April 29, 1987; 9:00 A.M. - 12:30 P.M.

MARINA BALLROOM 4

(Hotel Convention Center)

\section{Moderators: Edward LaGamma and Joseph B. Warshaw}

1. 9:00 ETHANOL INDUCED DEPRESSION OF DNA SYNTHESIS IN ASTROCYTES. W. Thomas Bass, Joseph J. Volpe. Washington Univ. School of Medicine, St. Louis Children's Hospital, Depts. of Pediatrics, Neurology, Biological Chemistry, St. Louis, MO. (Abstract 222).

2. 9:15 DEVELOPMENT OF TRANSSYNAPTIC REGULATION OF ADRENAL TRANSMITTERS. E.F. La Gamma, J.E. Adler. Pediatrics \& Neurobiology, SUNY at Stony Brook, and Neurology, Cornell Medical Center, NY. (Abstract 266).

3. 9:30 CEREBRAL ANTI-OXIDANT MECHANISMS OF THE FETAL GUINEA PIG BRAIN DURING GESTATION AND THE EFFECT OF MATERNAL HYPOXIA. Om P. Mishra, Maria Delivoria-Papadopoulos. Univ. of Pennsylvania School of Medicine, Dept. of Physiology, Philadelphia, PA. (Abstract 277). 
4. 9:45 THE CIRCADIAN-GATED TIMING OF BIRTH IN RATS: DISRUPTION BY MATERNAL SCN LESIONS OR BY REMOVAL OF THE FETAL BRAIN. Steven $M$. Reppert, William J. Schwartz, David R. Weaver. Children's and Neurology Services, Massachusetts General Hospital and Harvard Medical School, Boston, MA. (Abstract 286).

5. 10:00 ANTIBODY STAINING AND IN SITU HYBRIDIZATION REVEALS THAT A SUBSET OF NEURONS IN THE RABBIT NEONATAL BRAIN PRODUCE INSULIN. Ruben Schechter, Lynn Karycki, Farouk Sadiq, Thomas Hilliard, Arnold Kahn. St. Louis Univ. and the Pediatric Research Institute, Cardinal Glennon Children's Hospital, Dept. of Pediatrics, St. Louis, MO. (Abstract 293).

6. 10:15 ISOTRETINOIN EFFECTS NEURAL CREST CELLS IN VITRO. Linda Smith-Thomas, Ira T. Lott, Marianne Bronner-Fraser. Univ. of California Irvine, Dept. of Peds., Neurology and Developmental Biology Ctr., Irvine, CA. (Abstract 296).

7. 10:30 COORDINATE ACTIVATION OF THE DOLICHOL-LINKED PATHWAY TO GLYCOPROTEINS IN DEVELOPING BRAIN. Joseph J. Volpe, Yoichi Sakakihara, Robert S. Rust. Washington Univ. School of Medicine, St. Louis Children's Hospital, Depts. of Pediatrics, Neurology, Biological Chemistry, St. Louis, MO. (Abstract 305).

8. 10:45 MEASUREMENT OF OXYGEN CONSUMPTION OF THE PELVIC LIM IN FETAL SHEEP. Randall B. Wilkening, David W. Boyle, Giacomo Meschia. (Spon. by Frederick C. Battaglia). Depts. of Pediatrics and Physiology, Univ. of Colorado School of Medicine, Denver, CO. (Abstract 310).

9. 11:00 HUMAN FETAL AND MATERNAL PLASMA AMINO ACID LEVELS IN NORMAL AND INTRAUTERINE GROWTH RETARDED (IUGR) GESTATIONS. William A. Gahl, Kypros H. Nicolaides, Isa Bernardini, Robert Bradley, Mark I. Evans. Section on Human Biochem. Gen., NICHD, Bethesda, MD, Harris B-C, OB,' King's Coll., London, Reproductive Genetics, OB-GYN., Wayne State Univ., Detroit, MI. (Abstract 242).

10. 11:15 PROTEIN TURNOVER IN TISSUES OF THE FETAL RAT FOLLOWING MATERNAL PROTEIN RESTRICTION. John D. Johnson, Tracy Dunham. Univ. of New Mexico, Dept. of Pediatrics, Albuquerque, NM. (Abstract 263).

11. 11:30 IMMATURITY ALTERS THE ENDOGENOUS LIPID LEVELS IN PLASMA LIPOPROTEINS (PLP) OF NEWBORN INFANTS. B. Koletzko, T. Maragi, H. White, R.M. Filler, M. Rapp, T. Heim. Depts. Pediatric, Surg. \& Nutr. Sci., Univ. Toronto, \& Res. Inst., Hosp. Sick Child., Toronto, Ontario, Canada. (Abstract 264).

12. 11:45 REDUCED TRANSFER OF CALCIUM ACROSS THE IN STTU PERFUSED PLACENTAE OF INTRAUTERINE GROWTH RETARDED (IUGR) RAT FETUSES. Zulf. Mughal, Richardus Ross, Reginald C. Tsang. Univ. Cincinnati, Cincinnati, OH. (Abstract 279).

13. 12:00 UPTAKE OF INTRAFETALLY ADMINISTERED 3H-1,25 DIHYDROX-VITAMIN D3 $(1,25)$ BY THE MATERNAL SMALL INTESTINE. Richardus Ross, Jane Florer, Mei Chen, Kevin Halbert (Spon. by Reginald C. Tsang). Univ. of Cincinnati Med. Ctr., Dept. of Peds., Cincinnati, OH. (Abstract 288). 
14. 12:15 ARTIFICIAL PLASMA VOLUME EXPANSION IN DAMS. EFFECT ON FETAL GROWTH. Claude Sansaricq, Myron Winick. NY Univ. Medical Center, Dept. of Pediatrics, New York, Columbia Univ. College of Physicians and Surgeons, New York, NY. (Abstract 290).

\title{
SUBSPECIALTY PLATFORM SESSION
}

\author{
DEVELOPMENTAL MORPHOLOGY AND TERATOLOGY \\ Wednesday, Apri1 29, 1987; 9:00 A.M. - 12:30 P.M. \\ SOUTH BALLROOM \\ (Hote1 Convention Center)
}

Moderators: Robert Brent and James Hanson

1. 9:00 FETAL VARICELLA SYNDROME. Arie L. Alkalay, Jeffrey J. Pomerance, David L. Rimoin. UCLA School of Medicine, Cedars-Sinai Medical Center, Division of Neonatology, Dept. of Pediatrics and Medical Genetics-Birth Defects Center, Los Angeles, CA. (Abstract 312).

2. $9: 15$ TERATOGENS FROM WEEKLY ORAL ETHANOL EXPOSURE IN A NON-HUMAN PRIMATE. Sterling K. Clarren, Douglas M. Bowden, Susan J. Astley. Univ. of Washington School of Medicine, Depts. of Pediatrics and Psychiatry and Behavioral Sciences, Seattle, WA. (Abstract 322).

3. $9: 30$ THE EFFECTS OF TERATOGENIC ANTISERA ON PROTEIN SYNTHESIS AND DEGRADATION BY THE CULTURED RAT CONCEPTUS. David A. Beckman, Joan E. Pugarelli, Thomas R. Koszalka, Marcela Jensen, John B. Lloyd, Robert L. Brent. Thomas Jefferson Univ., Philadelphia, PA and Dept. of Biological Science, Univ. of Keele, UK. (Abstract 314).

4. $9: 45$ EFFECTS OF VITAMIN SUPPLEMENTATION ON THE OCCURRENCE OF NEURAL TUBE DEFECTS IN THE RAT. Janine E. Polifka, Heidi R. Russ, Robert L. Brent. Thomas Jefferson Univ., Dept. of Peds., Philadelphia, PA. (Abstract 342).

5. 10:00 LACK OF EVIDENCE FOR CRANIO-FACIAL DYSMORPHISM IN CHILDREN WITH AIDS. Tariq M. Sheikh, Qutub H. Qazi, Senih Fikrig, Howard Menikoff. Dept. of Peds., SUNY-Health Science Centerr, at Brooklyn, NY. (Abstract 347).

6. 10:15 MATERNAL DRINKING AND FETAL CLUBFOOT. Silvia Iosub, Mahrukh Bamji, Richard K. Stone, Herbert Rich, Donald S. Gromisch, Edward Wasserman (Spon. by Lawrence R. Shapiro). New York Medical College, Metropolitan and Lincoln Hospitals, Dept. of Pediatrics, NY. (Abstract 333).

7. 10:30 GENITOURINARY TRACT DYSMORPHOLOGY AND MATERNAL COCAINE USE. Ira Chasnoff, Gay Chisum (Spon. by James Stockman, III). Northwestern Univ. Medical School, Dept. of Pediatrics, Chicago, IL. (Abstract 317). 
8. 10:45 RETT SYNDROME: ADDITIONAL FINDINGS FROM 7 CASES. John B. Moeschler, Catherine E. Charman, Susan Z. Berg, John M. Graham, Jr., (Spon. by R.Z. Klein). Dartmouth Medical School, Dartmouth-Hitchcock Medical Ctr., Clinical Genetics and Child Development Ctr. Dept of Maternal \& Child Health, Hanover, NH. (Abstract 340).

9. 11:00 MYOPATHY (SKELETAL AND CARDIAC) AND WHISTLING FACE SYNDROME (WF). Wladimir Wertelecki, David G. Laycock, Duane W. Superneau. Univ. of South Alabama Coll. of Medicine, Univ. of South Alabama Medical Center, Dept. of Medical Genetics, Mobile, AL (Abstract 352).

10. 11:15 AMYOPLASIA: AUTOSOMAL RECESSIVE INHERITANCE IN TWO FAMILIES. Daniel H. Polk, Robin D. Clark, Donna Eteson (Spon. by Larry Shapiro). Dept. of Peds., King-Drew and Harbor-UCLA Medical Ctr., Los Angeles and Torrance, CA. (Abstract 343).

11. 11:30 A NEW X-LINKED RECESSIVE SYNDROME WITH BRAIN, HEART AND GENITAL MALFORMATIONS. Vickie L. Zurcher, Ali M. Yazdy (Spon. by Irwin A. Schafer). Case Western Reserve Univ. at Cleveland Metropolitan General Hospital, Dept. of Peds., Cleveland, OH. (Abstract 354).

12. $11: 45$ FAMILIAL NEPHRITIS, PROXIMAL RENAL TUBULAR DYSFUNCTION (PRTD), DEAFNESS, PRURITIS, ECZEMA AND HEPATOSPLENOMEGALY: A NEW SYNDROME. P. Kaplan, E. Reece, B.S. Kaplan. Dept. of Peds., The Montreal Children's Hosp., Montreal, Quebec, Canada. (Abstract 336).

13. 12:00 PROXIMAL 15q DELETION IN A FATHER AND SON WITH ISOLATED OBESITY. Jane E. O'Brien, Murray Feingold, Wayne A. Miller. NBDC Brighton, MA. (Abstract 341).

14. 12:15 TANDEM DUPLICATION OF CHROMOSOME 1q IN FRYNS SYNDROME. R.D. Clark, T. Mohandas, M. Fenner-Gonzales, (Spon. by L.J. Shapiro). Harbor-UCLA Med. Ctr., Depts. of Peds. and Pathology, Torrance, CA. (Abstract 321).

\author{
SUBSPECIALTY PLATFORM SESSION \\ IMMUNOLOGY II \\ Wednesday, April 29, 1987; 9:00 A.M. - 12:30 P.M. \\ MAGNOLIA $C$ \\ (Embassy/Magnolia Center)
}

Moderators: Steven Douglas and Steven M. Koh1

1. 9:00 A NOVEL IN VIVO HUMAN CYTOTOXIC T CELL. John L. Sullivan, Blake E. Tomkinson. Univ. Mass. Med. School, Dept. of Pediatrics, Worcester, MA. (Abstract 872).

2. 9:15 PARADOXICAL INHIBITORY AND STIMULATORY EFFECTS OF HERPES SIMPLEX VIRUS (HSV) ON LYMPHOKINE-ACTIVATED KILLER (LAK) CELLS. Terry W. Chin, Susan Plaeger-Marshall, Bonnie Ank, Sheila Strom, E. Richard Stiehm. Dept. of Pediatrics, UCLA, Los Angeles, CA. (Abstract 815). 
3. 9:30 DELAYED PRODUCTION OF INTERFERON-GAMMA (IFNgamma) AND TUMOR NECROSIS FACTOR (TNFalpha) BY MONONUCLEAR CELLS (MC) OF HERPES SIMPLEX VIRUS (HSV) INFECTED NEONATES (NB). Sandra Burchett, Kathey Mohan, Larry Corey, Christopher B. Wilson. Dept. of Pediatrics, Univ. of Washington, Seattle, WA. (Abstract 814).

4. 9:45 CYCLIC AMP INHIBITS NEUTROPHIL ADHERENCE BY BLOCKING SURFACE EXPRESSION OF THE CELL ADHESION MOLECULE, CR3. M. Tosi, M. Berger. Case Western Reserve Univ., Dept. of Pediatrics, Cleveland, OH. (Abstract 874).

5. 10:00 ONTOGENY OF HUMAN CD4 LYMPHOCYTE SUBPOPULATIONS FOLLOWING BONE MARROW TRANSPLANTATION. John W. Sleasman, Douglas J. Barrett. Univ. of Florida College of Medicine, Dept. of Pediatrics, Gainesville, FL. (Abstract 870).

6. 10:15 RADIATION EFFECTS ON THYMIC EPITHELIUM ARE PARTIALLY RESPONSIBLE FOR THE T-CELL DEFICITS OBSERVED IN BONE MARROW TRANSPLANT RECIPIENTS. Susan E. Wiedmeier, Wolfram Samlowski, Clark J. Rasmussen, Raymond A. Daynes (Spon. by Harry R. Hill). Univ. of Utah Medical Center, Dept. of Pathology, Salt Lake City, UT. (Abstract 882).

7. 10:30 INTERLEUKIN 2 (IL-2) RESTORATION OF DEFECTIVE IN VITRO LYMPHOCYTE PROLIFERATION FOLLOWING BONE MARROW TRANSPLANTATION (BMT). Carl Lenarsky, Kenneth Weinberg, Juanita Peterson, Robertson Parkman. Children's Hospital of Los Angeles, Division of Research Immunology, Los Angeles, CA. (Abstract 841).

8. 10:45 SERONEGATIVE JRA PATIENTS EXPRESS THE MAJOR RHEUMATOID FACTOR CROSS-REACTIVE IDIOTYPE. Josiah Wedgwood, Norman Ilowite, Amy Lewison-Nisen, Vincent Bonaqura (Spon. by K. King). SUNY Stony Brook and Schnieder Children's Hospital of LIJMC, Dept. Peds., Div. of Immunology, New Hyde Park, NY. (Abstract 878).

9. 11:00 THE PRESENCE OF IgA-RHEUMATOID FACTOR IN ACTIVE JUVENILE RHEUMATOID ARTHRITIS. Riva Brik, Sharyn M. Walker, Deborah K. McCurdy. Univ. of Southern California, Children's Hospital of Los Angeles, Depts. of Pediatrics and Microbiology, Los Angeles, CA. (Abstract 813).

10. 11:15 THE ROLE OF IgA1 RHEUMATOID FACTOR (RF) IN THE FORMATION OF IgA - CONTAINING CIRCULATING IMMUNE COMPLEXES (CIC) IN HENOCH-SCHONLEIN PURPURA (HSP). Frank T. Saulsbury (Spon. by Robert L. Chevalier). Univ. of Virginia Medical Center, Dept. of Pediatrics, Charlottesville, VA. (Abstract 861).

11. 11:30 DYSLIPOPROTEINEMIA IN PEDIATRIC SYSTEMIC LUPUS ERYTHEMATOSUS. Norman T. Ilowite, Paul Samue1, Marc S. Jacobson (Spon. by Philip Lanzkowsky). SUNY at Stony Brook, Schneider Children's Hospital of Long Island Jewish Medical Center, Dept. of Peds., New Hyde Park, NY. (Abstract 833). 
12. 11:45 LONGITUDINAL STUDY OF HIV ANTIBODY AND ANTIGEN IN INFANTS AND CHILDREN. F. Cohen, J.S. Webber, E.C. Moore, G. Dawson, M. Leuther, P.M. Long, E.M. Ostrea. Wayne State Univ., Children's Hospital of Michigan, Dept. of Peds., Detroit, and Abbott Laboratories, No. Chicago, IL. (Abstract 819).

13. 12:00 TRANSFUSION-ACQUIRED HUMAN IMMUNODEFICIENCY VIRUS (HIV) INFECTION IN NEONATES. Frank T. Saulsbury, Randolph F. Wykoff, Robert J. Boyle (Spon. by Robert L. Chevalier). Univ. of Virginia Medical Center, Dept. of Pediatrics, Charlottesville, VA. (Abstract 862).

14. 12:15 CLINICAL AND IMMUNOLOGIC FEATURES OF PEDIATRIC AIDS-RELATED COMPLEX (PARC). Naynesh Kamani, Hylton Lightman, Ira Leiderman, Leonard Krilov (Spon. by Philip Lipsitz). SUNY at Stony Brook, Schneider Children's Hospital of LIJMC, Dept. of Peds, New Hyde Pk., NY and Mt. Sinai School of Medicine, Division of Clinical Immunology, New York, NY. (Abstract 837).

\author{
SUBSPECIALTY PLATFORM SESSION \\ INFECTIOUS DISEASES I \\ Wednesday, April 29, 1987; 9:00 A.M. - 12:30 P.M. \\ EMBASSY WEST \\ (Embassy/Magnolia Center) \\ Moderators: Bascom Anthony and Robert S. Daum
}

1. 9:00 PEDIATRIC HUMAN IMMUNODEFICIENCY VIRUS (HIV) INFECTIONS: FACTORS INFLUENCING CASE IDENTIFICATION AND PROGNOSIS. Gwendolyn B. Scott, $M$. Mastrucci, S. Hutto, W. Parks (Spon. by W.W. Cleveland). Dept. of Pediatrics, Univ. of Miami School of Medicine, Miami, FL. (Abstract 962).

2. 9:15 INCREASING INCIDENCE OF HETEROSEXUAL TRANSMISSION OF THE HUMAN IMMUNODEFICIENCY VIRUS (HIV) IN MOTHERS OF INFANTS WITH AIDS OR ARC. Andrew A. Wiznia, Jay M. Kashkin, John W. Scott, Larry I. Bernstein, Samuel Grubman, Arye Rubinstein. Albert Einstien College of Medicine, Dept. of Pediatrics, Bronx, NY. (Abstract 985).

3. $9: 30$ RETROVIRAL ANTIGENEMIA IN CHILDREN WITH HIV INFECTION. William Borkowsky, Keith Krasinski, Deborah Paul, Robert Lawrence, Tiina Moore, Sulachni Chandwani. NYU Medical Center, Dept. of Pediatrics, New York, N.Y. and Abbott Laboratories, Chicago, IL. (Abstract 892).

4. 9:45 REVERSE TRANSCRIPTASE (RT) ACTIVITY AND RETROVIRAL SEROLOGY IN KAWASAKI DISEASE (KD). Anne H. Rowley, Bernard J. Poiesz, John L. Sullivan, Stanford T. Shulman. Northwestern Univ. Med. Sch., Children's Memorial Hospital, Dept. of Ped., Chgo., IL, SUNY Health Sciences Ctr., Dept. of Med., Syracuse, NY, and Univ. Massachusetts, Depts. of Ped., Worcester, MA. (Abstract 955). 
5. 10:00 REVERSE TRANSCRIPTASE ACTIVITY (RTA) IN PERIPHERAL BLOOD MONONUCLEAR CELL (PBMC) CULTURES (CXS) FROM PATIENTS (PTS) WITH KAWASAKI DISEASE (KD). Jane C. Burns, Raif S. Geha, Jane W. Newburger, Fred S. Rosen, Mary M. Walsh, Amy L. Reinhart, Alice S. Huang, Donald Y.M. Leung. Harvard Medical School, Children's Hospital, Dept. of Medicine, Boston, MA. (Abstract 896).

6. 10:15 ASSOCIATION OF KAWASAKI SYNDROME WITH ATOPIC DERMATITIS. Catherine L. Brosius, Jane W. Newburger, Jane C. Burns, Patricia Hojonowski-Diaz, Donald Y.M. Leung (Spon. by Raif Geha). Harvard Medical School, The Children's Hospital, Dept. of Cardiology and Medicine, Boston, MA. (Abstract 895).

7. 10:30 FIRST CLINICAL TRIAL WITH SABIN INACTIVATED POLIO VACCINE. Jody R. Murph, Charles Grose, Gilbert J. Cuthbertson, Christina Mickiewicz, Steve Mento, Frank Cano. Univ. of Iowa, Dept. of Pediatrics, Iowa City and Lederle Laboratories. (Abstract 942).

8. 10:45 IMPAIRED NATURAL IgG2 ANTIBODY (AB) RESPONSE TO POLYSACCHARIDE ANTIGENS AND DECREASED Km (1)-A2m(2) ALLOTYPES IN CYSTIC FIBROSIS (CF). R. B. Moss, Y.P. Hsu, N.J. Lewiston, G. deLange. Dept. of Pediatrics, Stanford Univ., Stanford, CA and Netherlands Red Cross Central Transfusion Laboratory, Amsterdam. (Abstract 940).

9. 11:00 RETICULOENDOTHELIAL CLEARANCE OF TYPE III GROUP B STREPAOCOCCI OPSONIZED WITH TYPE III SPECIFIC MONOCLONAL ANTIBODIES OF IgM OR IgG2a ISOTYPES IN AN EXPERIMENTAL RAT MODEL. Ann 0 . Shigeoka, James $M$. Bathras, Seth H. Pincus, Harry R. Hill. Univ. of Utah School of Medicine, Dept. of Pediatrics and Pathology, Salt Lake City, UT. (Abstract 964).

10. 11:15 CLEARANCE OF HAEMOPHILUS INFLUENZAE TYPE b (Hib) BACTEREMIA REQUIRES C3 FIXATION BUT NOT LYSIS IN THE NONIMMUNE HOST. Gary J. Noel, Steven Katz, Paul J. Edelson. Cornell U. Med. Coll., The New York Hospital, Depts. Pediatrics and Otorhinolaryngology, NY. (Abstract 944).

11. 11:30 DELETERIOUS EFFECT OF IMMUNE GLOBULIN IN THE TREATMENT OF $\underline{\mathrm{H}}$. INFLUENZAE B INFECTION IN INFANT RATS. J. Schreiber, C. Basker, C Priehs, G. Siber. Harvard Medical School, Dana-Farber Cancer Inst., Lab. of Infectious Diseases, and Mass. Public Health Biologic Laboratories, Boston, MA. (Abstract 961).

12. $11: 45$ SUSCEPTIBILITY TO INVASIVE $\underline{\mathrm{H}}$. INFLUENZAE (Hi) INFECTION IMMEDIATELY AFTER IMMUNIZATION WITH THE CAPSULAR VACCINE. Sunil $\mathrm{K}$. Sood, John S. Schreiber, George R. Siber, Robert S. Daum. Tulane U, New Orleans, and Dana-Farber Cancer Institute, Harvard U, Boston, MA. (Abstract 967).

13. 12:00 IGG RESPONSES TO $\underline{H}$. INFLUENZAE TYPE B (HIB) AND PNEUMOCOCCAL (PN) TYPES 3 (P-3) AND 23 (P-23) POLYSACCHARIDES (PS) IN CHILDREN DEVELOPING HIB DISEASE DESPITE VACCINATION WITH HIB PS VACCINE. Dan $M$. Granoff, Penelope G. Shackelford. Wash. Univ. Sch. of Med., \& Children's Hosp., St. Louis, MO. (Abstract 911). 
14. 12:15 EFFECT OF OLIGOSACCHARIDE (OS) CHAIN LENGTH, TERMINAL GROUP, AND HAPTEN LOADING ON THE SERUM ANTIBODY (Ab) RESPONSE OF 1-YR-OLD INFANTS TO $\mathrm{H}$. INFLUENZAE B CAPSULAR ANTIGEN (PRP) CONJUGATED TO THE DIPHTHERIA PROTEIN CRM197. Porter W. Anderson, Michael E. Pichichero, David M. Connuck, David Korones, John M. Zahradnik (Spon. by K.R. Powe11). Dept. Peds, U. Rochester, NY; Baylor College of Medicine, Houston, TX (Abstract 886).

\author{
SUBSPECIALTY PLATFORM SESSION \\ METABOLISM AND DIABETES I \\ Wednesday, April 29, 1987; 9:00 A.M. - 12:30 P.M. \\ EMBASSY EAST \\ (Embassy/Magnolia Center)
}

Moderators: Dorothy Becker and Morey Haymond

1. 9:00 SJOGREN-LARSSON SYNDROME (SLS): DEFICIENT FATTY ALCOHOL: NAD OXIDOREDUCTASE (FAO) ACTIVITY IN CULTURED FIBROBLASTS. William B. Rizzo, Andrea L. Dammann, Debra Craft (Spon. by Karl S. Roth). Med. College of VA, Depts. of Pediatrics and Human Genetics, Richmond, VA. (Abstract 1032).

2. 9:15 THE ENZYMATIC BASIS FOR THE METABOLISM AND INHIBITORY ACTION OF VALPROATE (VP): DEHYDROGENATION OF VP-COA BY 2-METHYL-BRANCHED CHAIN ACYL-CoA DEHYDROGENASE (2-me BCAD). Michinori Ito, Yasuyuki Ikeda, Gaetano Finocchiaro, John Arnez, Kay Tanaka (Spon. by W. Roy Breg). Yale School of Medicine, New Haven, CT and CUNY, NY. (Abstract 1015).

3. $9: 30$ EFFECTS OF SUBLETHAL DOSES OF ENDOTOXIN AND ASPIRIN (ASA) ON RAT HEPATIC ENERGY METABOLISM: AN ANIMAL MODEL OF REYE SYNDROME. L. Kilpatrick-Smith, S.D. Douglas, R.A. Polin, B.E. Corkey. Univ. of PA School of Medicine, Depts. of Pediatrics and Biochemistry, Philadelphia, PA. (Abstract 1016).

4. 9:45 A SINGLE DOSE OF PANTOTHENATE, CYSTEINE AND CARNITINE INCREASES LIVER COENZYME A AND ACETYL COA LEVELS IN NORMAL INFANT MICE AND SUBSTANTIALLY REVERSES VALPROATE-INDUCED HEPATIC DYSFUNCTIONS: POSSIBLE CLINICAL SIGNIFICANCE. Jean Holowach Thurston, Richard E. Hauhart. Washington Univ. Medical Center, Children's Hospital, Dept. of Pediatrics, St. Louis, MO. (Abstract 1013).

5. 10:00 HEPATIC ACYL-COA PROFILES IN RIBOFLAVIN DEPRIVATION-INDUCED MULTIPLE ACYL-CoA DEHYDROGENASE DEFICIENCY. Charles A. Stanley, Barbara E. Corkey, George Booz, Daniel E. Hale, M. Clay Glennon, Gerard T. Berry. Univ. of PA School of Medicine, Children's Hospital of Philadelphia, Dept. of Pediatrics, Philadelphia, PA. (Abstract 1048).

6. 10:15 L-CARNITINE (C) DOES NOT PROTECT AGAINST FASTING IN MEDIUM CHAIN ACYL CoA DEHYDROGENASE (MCAD) DEFICIENCY. William R. Treem, Stephen I. Goodman, Charles A. Stanley. Depts. of Pediatrics, Georgetown Univ., Univ. of CO, Univ. of PA, Schools of Medicine, Washington, DC, Denver, CO and Philadelphia, PA. (Abstract 1050). 
7. 10:30 FATAL CARDIOMYOPATHY IN CYTOCHROME OXIDASE DEFICIENCY: LIGHT MICROSCOPIC, HISTOCHEMICAL, BIOCHEMICAL AND ELECTRONMICROSCOPIC STUDY. C.H. Chang, R. Poland, B.H. Robinson, S. DiMauro. Wayne State Univ. School of Medicine, Children's Hospital of Michigan, Dept. of Pediatrics, Detroit, MI and Columbia Univ. College of Physicians and Surgeons, New York, NY. The Hospital for Sick Children, Dept. of Pediatrics, Toronto. (Abstract 998).

8. 10:45 EFFECT OF CYSTINE DIMETHYLESTER (CDM) ON RENAL TUBULAR FUNCTION, A MODEL OF FANCONI SYNDROME. John W. Foreman, Judithann Lee, Margaret Ann Bowring, Stanton Segal. Univ. of Pennsylvania School of Medicine, The Children's Hospital of Philadelphia, Dept. of Pediatrics, Philadelphia, PA. (Abstract 1006).

9. 11:00 SODIUM BENZOATE (SB) INCREASES FREE TRYPTOPHAN (TRP) IN BLOOD AND SEROTONIN (5-HT) FLUX IN CORTEX OF OTC DEFICIENT SPF MICE. Susan L. Hyman, Joseph T. Coyle, Ijaz Qureshi, Mark L. Batshaw. Depts. Peds., Psych. and Kennedy Inst., Johns Hopkins Meds Inst., Baltimore, MD and Hospital Ste. Justine, Univ. Montreal, Montreal, Canada. (Abstract 1014).

10. 11:15 DIHYDROPTERIDINE REDUCTASE DEFICIENCY: CLONING OF THE DIHYDROPTERIDINE REDUCTASE GENE, ANALYSIS OF MUTANT CELLS, AND PROSPECTS FOR GENETIC THERAPY. Fred. D. Ledley, Jean Lockyer, Seymor Kaufman, Sheldon Milstein, Savio L.C. Woo (Spon. by Arthur Beaudet). Howard Huges Medical Institute, Dept. of Cell Biology, Baylor College of Medicine, Houston, TX and Laboratory of Neurochemistry, National Institutes of Health, Bethesda, MD. (Abstract 1021).

11. 11:30 ASPARTAME INTAKE AND ITS EFFECT ON PHENYLALANINE (PHE) AND PHE METABOLITES. Reuben Matalon, Kimberlee Michals, Debra Sullivan, Paul Levy. Univ. of Illinois at Chicago, Depts. of Pediatrics, Nutrition and Medical Dietetics and Epidemiology and Biometry, Chicago, IL. (Abstract 1026).

12. 11:45 A NOVEL METABOLIC PATHWAY FOR 25-HYDROXY VITAMIN D2 IN A MAMMALIAN KIDNEY. Satyanarayana G. Reddy, Kou-Yi Tserng, Rahul Ray, Brian DeCosta, Michael F. Holick (Spon. by R. Marshall). CWRU at Cleveland, Metro General Hospital and VA Medical Center, Depts. of Pediatrics and Pharmacology, Cleveland, $\mathrm{OH}$ and Human Nutrition Research Center at Tufts Univ., Boston, MA. (Abstract 1029).

13. 12:00 IN VIVO TIME COURSE OF MUSCLE PHOSPHOCREATINE, PHOSPHORUS AND ADENOSINE TRIPHOSPHATE DURING TREATMENT OF RICKETS. Charles E. Mize, Ronald Corbett, Ricardo Uauy, Ray Nunnally, Susanna Williams. Univ. of Texas Health Science Center at Dallas, Dept. of Pediatrics and Radiology, Dallas, TX. (Abstract 1027).

14. 12:15 SULFUR AND METHYL BALANCES IN A MAN WITH HEPATIC METHIONINE ADENOSYLTRANSFERASE (MAT) DEFICIENCY. W.A. Gahl, I. Bernardini, J.D. Finkelstein, A. Tangerman, J.J. Martin, H.J. Blom, K.D. Mullen, H.S. Mudd. NICHD, NIDDKD, NIMH, Bethesda, MD; VA Medical Center, Washington, DC, St. Radoud Univ. Hospital, Netherlands. (Abstract 1007). 


\section{SUBSPECIALTY PLATFORM SESSION \\ NEONATOLOGY II \\ Wednesday, April 29, 1987; 9:00 A.M. - 12:30 P.M. \\ GRAND BALLROOM \\ (Hote1 Convention Center) \\ Moderators: John Kattwinkel and Bradley Thach}

1. 9:00 EFFECTS OF INDOMETHACIN PRETREATMENT ON CAUDATE BLOOD FLOW IN ACUTE, SEVERE ASPHYXIA IN PIGLETS. Massroor Pourcyrous, Charles Leffler, David Busija (Spon. by Henrietta Bada). Univ. of Tenn., Depts. of Pediatrics and Physiology and Biophysics, Memphis, TN. (Abstract 1202).

2. 9:15 PIAL ARTERIOLAR RESPONSES DURING RECOVERY FROM ACUTE ASPHYXIA IN PIGLETS. Uma R. Kotagal, John H. Reuter, Edward F. Donovan, Michael Donnelly. Univ. of Cincinnati, Dept. Pediatrics, Div. Neonatology., Cincinnati, OH. (Abstract 1157).

3. $9: 30$ BRAIN MATURATION IN PRETERM INFANTS DURING EARLY POSTNATAL DEVELOPMENT. Terri A. Slagle, Michael Oliphant, Steven J. Gross. SUNY-Health Science Ctr., Depts. of Pediatrics and Radiology, Syracuse, NY. (Abstract 1221).

4. $9: 45$ RISK FACTORS ASSOCIATED WITH INFANT DEATH AFTER DISCHARGE FROM AN ICN. R. Piecuch, R. Clyman, R. Ballard. Dept. of Pediatrics, Mount Zion Hospital, San Francisco, CA. (Abstract 1197).

5. 10:00 OUTCOME OF PERIVENTRICULAR-INTRAVENTRICULAR HEMORRHAGE (PIVH) AT 2 YEARS OF AGE IN 484 VERY PRETERM INFANTS. Margot van de Bor, $S$. Pauline Verloove-Vanhorick, Ronald Brand, William Baerts, Jan H. Ruys (Spon. by William Oh). Univ. Hosp. Depts. of Pediatrics (Neonatal Ctr.) and Medical Statistics, Leiden, The Netherlands. (Abstract 1237).

6. 10:15 VENTRICULOPERITONEAL SHUNTS IN POST-HEMORRHAGIC VENTRICULOMEGALY IN LESS THAN OR EQUAL TO 1250 G NEONATES. Seetha Shankaran, Thomas Koepke, Rima Dajani, Mary Bedard, Eunice Woldt (Spon. by Ronald Poland). Wayne State Univ. Sch of Med., Children's Hosp. of Michigan, Dept. of Pediatrics, Detroit, MI. (Abstract 1216).

7. 10:30 MAGNETIC RESONANCE (MR) IMAGING OF NEONATAL HYPOXIC-ISCHEMIC ENCEPHALOPATHY. Craig B. McArdle, C. Joan Richardson, Susan E. Keeney, Eugene W. Adcock, Madan V. Kulkarni, C. Keith Hayden, Eugenio G. Amparo. Univ. of Texas Health Sci. Ctr. and Univ. of Texas Med. Branch, Depts. of Radiology and Pediatrics, Houston and Galveston, TX. (Abstract 1168).

8. 10:45 BRAIN CELL MEMBRANE DYSFUNCTION FOLLOWING SINGLE AND REPEATED APNEA IN NEWBORN PIGLETS. Jan M Goplerud, Om O. Mishra, L. Craig Wagerle, Maria Delivoria-Papadopoulos. Univ. of Penn. School of Medicine, Depts. of Pediatrics and Physiology, Philadelphia, PA. (Abstract 1130). 
9. 11:00 HYPEROXIA (H), DEXAMETHASONE (D) AND NEWBORN ALVEOLAR MACROPHAGE (AM) FUNCTION. Michael P. Sherman, Laurie A. Campbell, Ernesto E. Aeberhard, Cynthia T. Barrett. Univ. of California School of Medicine, UCLA Medical Ctr., Dept. of Pediatrics, Los Angeles, CA. (Abstract 1218).

10. 11:15 THE REPORTED HYPOXEMIA DURING LIPID INFUSION IN NEONATES IS LIKELY DUE TO A DECREASE IN ALVEOLAR OXYGEN TENSION (PAO2). Jean Tay-Uyboco, Jaques Belik (Spon. by Henrique Rigatto). Univ. of Manitoba, Health Sciences Ctr., Dept. of Pediatrics, Winnipeg, Canada. (Abstract 1228).

11. $11: 30$ AUTOREGULATION OF BLOOD FLOW AND OXYGEN UPTAKE IN THE DEVELOPING INTESTINAL CIRCULATION. P. Nowicki (Spon. by G. Morrow). Ohio State Univ., and Children's Hosp., Dept. of Pediatrics, Columbus, $\mathrm{OH}$. (Abstract 1186).

12. $11: 45$ DEVELOPMENT OF FASTING MOTILITY PATTERNS IN SMALL INTESTINE OF TERM AND PRETERM INFANTS. Rathna P. Amarnath, Carol L. Berseth, Juan R. Malagelada (Spon. by Gerald S. Gilchrist). Dept. of Peds., and Gastroenterology Unit, Mayo Clinic, Rochester, MN. (Abstract 1062).

13. 12:00 BILIRUBIN AND CELLULAR FUNCTIONS - TOXICITY IN N-115 CELLS. Yair Amit, Mark J. Poznansky, David Schiff. Univ. of Alberta, Depts. of Pediatrics and Physiology, Edmonton, Alberta, Canada. (Abstract 1064).

14. 12:15 A DIFFERENCE IN MORTALITY OF TWO JAUNDICED RAT STRAINS. Paul E. Stobie, Car1 T. Hansen, Rodney L. Levine. NIH, National Heart, Lung, and Blood Institute and Veterinary Resources Branch, Bethesda, MD. (Abstract 1225).

\title{
SUBSPECIALTY PLATFORM SESSION
}

\author{
NEPHROLOGY II \\ Wednesday, April 29, 1987; 9:00 A.M. - 12:30 P.M. \\ MARINA BALLROOM 2 \\ (Hotel Convention Center)
}

Moderators: Billy S. Arant, Jr. and Warren Grupe

1. 9:00 ALTERED TRANSTUBULAR ORGANIC ANION (OA) TRANSPORT MEDIATES RENAL TUBULAR CYST FORMATION (RTCF) IN-VITRO. Ellis D. Avner, William E. Sweeney, Michael C. Young, Demetrius Ellis. Univ. of Pittsburgh School of Medicine, Children's Hosp. of Pittsburgh, Pittsburgh, PA. (Abstract 1789).

2. $9: 15$ PATHOGENESIS OF HYPERCALCIURIA IN BARTTER'S SYNDROME (BS). Consuelo Restrepo, Thomas Welch, William Bergstrom, George Hug. Children's Hosp. Research Foundation, Cincinnati, OH; SUNY Health Sciences Ctr., Syracuse, NY. (Abstract 1856). 
3. 9:30 IMMUNE RESPONSIVENESS IN THE YOUNG UREMIC CHILD: IMPLICATIONS FOR TRANSPLANTATION. Robert B. Ettenger, Harry Prince, Dorit Ben-Ezer, Isidro B. Salusky, Richard N. Fine. UCLA School of Medicine, Dept. of Pediatrics, Los Angeles, CA. (Abstract 1805).

4. $9: 45$ CHRONIC RENAL DENERVATION (DNx): GLOMERULAR HEMODYNAMIC RESPONSES TO WATER DEPRIVATION. Juan C. Pelayo (Spon. by John W. Sparks). Univ. of Colorado, School of Medicine, Depts. of Pediatrics and Medicine, Denver, CO. (Abstract 1850).

5. 10:00 EFFECTS OF HYPERGLYCEMIA ON RENAL HEMODYNAMICS OF THE ISOLATED PERFUSED RAT KIDNEY (IPRK). Valerie L. Johnson, Eduardo M. Perelstein, Wallace W. McCrory. Cornell Univ. Medical College, Dept. of Pediatrics, New York, NY. (Abstract 1828).

6. 10:15 ONTOGENY OF INTRARENAL RENIN AND ANGIOTENSINOGEN GENE TRANSCRIPTION IN WISTAR-KYOTO AND SPONTANEOUSLY HYPERTENSIVE RATS. R. Ariel Gomez, Kevin R. Lynch, Robert L. Chevalier, Neysa Wilfong, Allen D. Everett, Robert M Carey, Michael J. Peach. Univ. of Virginia, Charlottesville, VA. (Abstract 1813).

7. 10:30 IMPAIRED HEMODYNAMIC RECOVERY FOLLOWING RELEASE OF CHRONIC PARTIAL URETERAL OBSTRUCTION (CPUO): EFFECT OF AGE. Robert L. Chevalier, R. Ariel Gomez, Catherine E. Jones. Univ. of Virginia, Dept. of Pediatrics, Charlottesville, VA. (Abstract 1799).

8. 10:45 RELEASE OF NEONATAL UNILATERAL CHRONIC PARTIAL URETERAL OBSTRUCTION (CPUO) RECIPROCALLY ALTERS ANGIOTENSIN (ANG)-MEDIATED VASCULAR TONE OF BOTH KIDNEYS. Robert L. Chevalier, R. Ariel Gomez, Catherine E. Jones. Univ. of Virginia, Dept. of Pediatrics, Charlottesville, VA. (Abstract 1800).

9. 11:00 IN VITRO INTERLEUKIN-2 RECEPTOR GENERATION BY PBL ISOLATED FROM SLE PATIENTS. Delbert R. Wigfall, Daniel J. Wallace, Rebecca S. Sakai, Stanley C. Jordan. UCLA, Cedars-Sinai Medical Ctr., Dept. of Peds., Division of Pediatric Nephrology, and Adult Rheumatology, Los Angeles, CA. (Abstract 1878).

10. 11:15 CONCLUSIVE EVIDENCE FOR THE EXISTENCE OF THE ANTIGEN OF HEYMANN NEPHRITIS (HN) IN NORMAL RAT SERUM AND ITS PARTIAL CHARACTERIZATION. John K. Kanalas, Sudesh P. Makker. Univ. of Texas Health Science Ctr., Dept. of Pediatrics/Nephrology, San Antonio, TX. (Abstract 1831).

11. 11:30 IMMORTALIZED GLOMERULAR EPITHELIAL CELLS AND TYPE II PNEUMOCYTES SHARE THE ANTIGENIC DETERMINANTS OF HEYMANN NEPHRITIS (HN) ANTIGEN. Sudesh P. Makker, John J. Kanalas, Robert V. Kotas. Univ. of Texas Health Science Ctr. at San Antonio, Divs. of Nephrology and Research, Dept. of Pediatrics, San Antonio, TX. (Abstract 1843).

12. 11:45 STIMULATION OF MESANGIAL CELL PGE2 BY PURIFIED C3b AND IMMUNE COMPLEXES: EVIDENCE FOR CR1 AND FC RECEPTORS. John E. Stork, Steven N. Emancipator (Spon. by Jeffrey L. Blumer). Case Western Reserve Univ., Rainbow Babies and Children's Hosp., Dept. of Pediatrics, Cleveland, OH. (Abstract 1865). 
13. 12:00 A REGULATORY SYSTEM FOR PRODUCTION OF SOLUBLE IMMUNE RESPONSE SUPPRESSOR (SIRS) IN NEPHROTIC SYNDROME. William Schnaper (Spon. by B.R. Cole). Washington Univ. School of Medicine, Jewish Hosp. of St. Louis, MO. (Abstract 1860).

14. 12:15 BOVINE SERUM ALBUMIN (BSA)-AN ANTIGENIC STIMULUS IN IGA NEPHROPATHY. Hui-Kim Yap, Rebecca S. Sakai, Keng-Thye Woo, Cheng-Hong Lim, Stanley C. Jordan. UCLA, Cedars-Sinai Medical Ctr., Dept. of Pediatrics, Division of Pediatric Nephrology, Los Angeles, CA and Dept. of Renal Medicine, Singapore General Hosp., Singapore, China. (Abstract 1879).

\title{
SUBSPECIALTY PLATFORM SESSION
}

\author{
NEUROLOGY \\ Wednesday, April 29, 1987; 9:00 A.M. - 12:30 P.M. \\ MAGNOLIA B \\ (Embassy/Magnolia Center)
}

Moderators: Joseph E. Pasternak and Joseph Volpe

1. 9:00 GUILLAIN-BARRE SYNDROME: FAVOURABLE LONG TERM OUTCOME. David M. Briscoe, Joseph B. McMenamin, Niall V. O'Donohoe, Thomas T. Reilly, Paul G. Moe. Our Lady's Hospital for Sick Children, Dublin, Ireland \& Univ. of Colorado Sciences Center and the Children's Hospital, Denver, Co. (Abstract 1892).

2. 9:15 ELEVATED BETA-ENDORPHINS IN RETT'S SYNDROME. Edwin C. Myer, Dale Morris, William B. Dewey (Spon. by Harold M. Maurer). Depts. of Neurology/Pediatrics and Pharmacology, Medical College of Virginia, Virginia Commonwealth Univ., Richmond, VA. (Abstract 1928).

3. $9: 30$ RETT SYNDROME: DIFFERENTIATION OF MOTOR AND BEHAVIORAL FEATURES FROM AUTISM. Alan K. Percy, Huda Y. Zoghbi, Kay R. Lewis, Joseph Jankovic. Baylor College of Medicine, Depts. of Pediatrics and Neurology and The Univ. of Texas Health Science Ctr. Medical School, Houston, TX. (Abstract 1932).

4. 9:45 PRESERVATION OF BRAINSTEM AND CEREBRAL BLOOD FLOW (CBF) IN TWO ASPHYXIATED NEWBORN INFANTS WITH CLINICAL BRAIN DEATH. Denis I. Altman, Jeffrey M. Perlman, William J. Powers, Beth K. Levy, Marcus E. Raichle, Joseph J. Volpe. Wash. Univ. Sch. of Med., St. Louis Child. Hosp., Depts. of Peds., Neurol., Radiol., St. Louis, MO. (Abstract 1884).

5. 10:00 DURATION OF VENTILATION IN NEONATAL MYOTONIC DYSTROPHY PREDICTS POOR OUTCOME. Peter Wong, Haresh Kirpalani, Gordon Murphy, Laurence Becker (Spon. by Barry T. Smith). The Hosp. for Sick Children, Depts. of Pediatrics and Pathology, Toronto, Ontario, Canada. (Abstract 1950). 
6. 10:15 MAGNETIC RESONANCE (MR) IMAGING OF NEONATAL INTRACRANIAL HEMORRHAGE. Susan E. Keeney, Craig B. McArdle, C. Joan Richardson, Madan V. Kulkarni, Eugene W. Adcock, III. Univ. of Texas Health Science Ctr. and Univ. of Texas Med. Branch, Depts. of Pediatrics and Radiology, Houston and Galveston, TX. (Abstract 1909).

7. 10:30 PROPHYLACTIC INDOMETHACIN FOR THE PREVENTION OF PERIVENTRICULAR HEMORRHAGE. William Hanigan, Gail Kennedy, Frank Roemisch, Robert Anderson, Tom Cusack, Tim Miller (Spon. by George Honig). Univ. of Illinois College Med., Peoria, Univ. Illinois Sch. Pub. Hlth., Chicago, and St. Francis Med. Ctr. Depts. Neurosci., Epidemiol-Biom., Radiology and Pediatrics, Peoria, IL. (Abstract 1906).

8. 10:45 INCIDENCE OF ABNORMAL ORGANIC ACID METABOLITES IN PATIENTS WITH SPINAL MUSCULAR ATROPHY. Hanna Mandel, Diane Africk, James Miller, John Willis, Carol Greene, Emmanuel Shapira. Tulane Univ. School of Medicine, Human Genetics Program, New Orleans, LA. (Abstract 1918).

9. 11:00 BRAIN SWELLING FOLLOWING ASPHYXIA IN THE TERM NEWBORN: CORRELATION OF INTRACRANIAL PRESSURE (ICP) AND CT FINDINGS WITH NEUROLOGIC OUTCOME. Brian A. Lupton, Alan Hill, Olof Flodmark, Michael F. Whitfield, Elke H. Roland. Univ. of British Columbia, B.C. Children's Hosp., Depts. of Paediatrics and Radiology, Vancouver, Canada. (Abstract 1916).

10. 11:15 CBF AND BRAIN EDEMA IN PERINATAL CEREBRAL HYPOXIA-ISCHEMIA. Dennis J. Mujsce, Melanie A. Boyer, Robert C. Vannucci. Penn State Univ. - Hershey Medical Ctr., Dept. of Pediatrics, Hershey, PA. (Abstract 1926).

11. 11:30 DOPPLER ULTRASONOGRAPHY (US) IN FULL-TERM (FT) HYPOXIC-ISCHEMIC ENCEPHALOPATHY (HIE). Jonathan Hellmann, Gloria Soto, Hasu Mackanjee, Alan Daneman (Spon. by Barry T. Smith). Depts. Ped. and Radiol., The Hosp. for Sick Children, Toronto, Canada. (Abstract 1907).

12. 11:45 BRAIN CELL MEMBRANE FUNCTION AND ENERGY METABOLISM FOLLOWING SEVERE HYPOCAPNIA IN NEWBORN PIGLETS. Maria Delivoria-Papadopoulos, L. Craig Wagerle, Jan M. Goplerud, Britton Chance, Om P. Mishra. Univ. of Pennsylvania School of Medicine, Depts. of Physiology and Biophysics, Philadelphia, PA. (Abstract 1900).

13. 12:00 NEUROTRANSMITTER ACTIVITY DURING PROLONGED AND BRIEF NEONATAL SEIZURE: A 1H NMR STUDY. Richard S.K. Young, Ognen A.C. Petroff, Susan L. Dunham, Barrett E. Cowan. Yale Univ. School of Medicine; Yale-New Haven Hospital; Depts. of Pediatrics and Neurology; New Haven, CT. (Abstract 1952).

14. 12:15 IN VIVO 31-P NMR MEASUREMENT OF CEREBRAL METABOLITE ALTERATIONS FOLLOWING NEONATAL INTRAVENTRICULAR HEMORRHAGE. Barbara Medoff-Cooper, Donald P. Younkin, Ronnie Guillet, Teresa Sinnwell, Britton Chance, Maria Delivoria-Papadopoulos. Univ. of PA Sch. of Med., Dept. of Pediatrics, Biophysics, and Physiology, Philadelphia, PA. (Abstract 1920). 


\title{
SUBPSPECIALTY PLATFORM SESSION
}

\author{
PULMONOLOGY II \\ Wednesday, April 29, 1987; 9:00 A.M. - 12:30 P.M. \\ MARINA BALLROOM 3 \\ (Hotel Convention Center)
}

Moderators: Thomas A. Haziniski and Michael A. Wall

1. 9:00 CHANGES IN BOMBESIN (B), CALCITONIN (C) AND SEROTONIN (S) IMMUNOREACTIVE PULMONARY NEUROENDOCRINE CELLS (PNEC) FOLLOWING PROLONGED MECHANICAL VENTILATION. Dana E. Johnson, Jane D. Wobken, Bonnie G. Landrum. Univ. of Minnesota Medical School. Univ. of Minnesota Hospital, Dept. of Pediatrics, Minneapolis, MN. (Abstract 1972).

2. 9:15 PULMONARY VASCULAR EXTRACTION OF NOREPINEPHRINE (NE) IN INFANTS WITH BRONCHOPULMONARY DYSPLASIA (BPD). Steven H. Abman, Michael S. Schaffer, James Wiggins, Reginald Washington, Marilyn Manco-Johnson, Robert R. Wolfe (Spon. by Ernest K. Cotton). Univ. of Colorado School of Medicine, Dept. of Pediatrics, Denver, Co. (Abstract 1955).

3. 9:30 ABSENCE OF DENSITY DEPENDENCE OF MAXIMAL EXPIRATORY FLOWS AT FUNCTIONAL RESIDUAL CAPACITY IN INFANTS WITH BRONCHOPULMONARY DYSPLASIA. Robert S. Tepper (Spon. by R. Schreiner). Indiana Univ. School of Medicine Dept. of Pediatrics, Indianapolis, IN. (Abstract 1995).

4. 9:45 EXTREME PREMATURITY, NOT HYALINE MEMBRANE DISEASE (HMD), IS LINKED WITH INCREASED AIR WAY RESPONSIVENESS AND ABNORMAL PULMONARY FUNCTION AT 10 TO 13 YEARS OF AGE. Michele Galdes-Sebaldt, James R. Sheller, Jens Grogaard, Mildred T. Stahlman. Vanderbilt Univ. School of Medicine, Depts. Peds. \& Med., Nashville, TN. (Abstract 1965).

5. 10:00 PLASMA ELEVATIONS OF A PROSTAGLANDIN (PG) METABOLITE IN ACUTE BRONCHIOLITIS (AB). David P. Skoner, Lawrence Caliguiri, Holly Davis, Philip Fireman. Children's Hospital, Pittsburgh, PA. (Abstract 1990).

6. 10:15 EARLY PSEUDOMONAS AERUGINOSA (PA) COLONIZATION IN YOUNG INFANTS WITH CYSTIC FIBROSIS (CF) IDENTIFIED BY NEWBORN SCREENING. Steven $\mathrm{H}$. Abman, Ronald J. Harbeck, Nancy A. Butler-Simon, Mary C. Reardon, John W. Ogle, Frank J. Accurso (Spon. by Ernest Cotton). Univ. of Colorado School of Medicine and National Jewish Hospital, Depts. of Pediatrics and Immunology, Denver, Co. (Abstract 1954).

7. 10:30 SODIUM HOMEOSTASIS IN CYSTIC FIBROSIS. Gregory J. Legris, Ulrich Hopfer, Janice G. Douglas, Dorr G. Dearborn, Cynthia G. Legris, Robert C. Stern. Case Western Reserve University, Rainbow Babies \& Children's Hospital, Depts. of Pediatrics, Medicine, Physiology and Biophysics, Cleveland, $\mathrm{OH}$. (Abstract 1977).

8. 10:45 PLASMA HISTAMINE ELEVATIONS IN ACUTE ASTHMA (AA). David P. Skoner, Richard Page, Barry Asman, Philip Fireman. Children's Hospital, Pittsburgh, PA. (Abstract 1991). 
9. 11:00 LEUKOTRIENE C4 (LTC4) RELEASE IN RESPIRATORY MUCOSA DURING NATURAL EXPOSURE TO RAGWEED IN RAGWEED SENSITIVE CHILDREN. B. Volovitz, S.L. Osur, P.L. Ogra. SUNY at Buffalo, Dept. of Pediatrics, Children's Hospital of Buffalo, NY. (Abstract 1997).

10. 11:15 DOSE RESPONSE OF BREATHING AND BEHAVIOR TO MORPHINE IN THE FETAL SHEEP. Shabih Hasan, David Lee, Dan Sitar, Carl Pinsky, Dale Gibson, Bogdan Nowaczyk, Don Cates, Henrique Rigatto. Univ. of Manitoba, Dept. of Pediatrics, Winnipeg, Manitoba, Canada. (Abstract 1969).

11. 11:30 PROLONGED APNEA IN INFANTS WITH RESPIRATORY SYNCYTIAL VIRUS (RSV) INFECTION IS SIMILAR TO APNEA OF PREMATURITY AND LARYNGEAL CHEMOREFLEX (LC) APNEA. Deborah L. Pickens, Georgia L. Schefft, Bradley T. Thach. Wash. Univ. Sch. of Med., St. Louis Children's Hospital, Dept. of Peds., St. Louis, MO. (Abstract 1981).

12. 11:45 HUMAN FETAL LARYNGOTRACHEAL DYNAMICS. J.C. Birnholz, E.E. Farre11 (Spon. by J. Pasternak). Depts. of Radiology (Rush-Presbyterian-St. Luke's Med. Center) and Div. Neonatology (Evanston Hosp.); Chicago \& Evanston, IL. (Abstract 1957).

13. 12:00 PHRENIC NERVE PACING: A LIFE TABLE ANALYSIS OF IMPLANTED COMPONENTS. Robert T. Brouillette, Michel N. Ilbawi, Anna S. Morrow, Debra E. Weese-Mayer, Carl E. Hunt. Northwestern Univ. Medical School, Children's Memorial Hospital, Dept. of Pediatrics and Surgery, Chicago, IL. (Abstract 1960).

14. 12:15 ANALYSIS OF BREATHING PATTERNS IN A PROSPECTIVE POPULATION DOES NOT PREDICT SUSCEPTIBILITY TO SUDDEN INFANT DEATH SYNDROME. Thomas $B$. Waggener, David P. Southal1, Louis A. Scott (Spon. by Ivan D. Frantz, III). Tufts Sch. of Med., New England Medical Center, Dept. of Pediatrics, Boston, Cardiothoracic Inst., Brompton Hospital, Dept. of Pediatrics, London. (Abstract 1998). 